\title{
TRIGONOCEPHALY - OUR EXPERIENCE AND TREATMENT IN THE REPUBLIC OF MACEDONIA
}

\author{
Vladimir Mircevski ${ }^{1}$, Elizabeta Zogovska ${ }^{2}$, Aleksandar Chaparoski ${ }^{1}$, Mile Micunovic ${ }^{3}$, Venko Filipce ${ }^{1}$, \\ Mirko Mishel Mirchevski ${ }^{5}$, Milenko Kostov ${ }^{1}$, Ljubica Micunovic ${ }^{4}$ \\ ${ }^{1}$ University Clinic for Neurosurgery, Clinical Center "Mother Teresa" Skopje, Macedonia \\ ${ }^{2}$ University Clinic for Plastic, Aesthetic and Reconstructive Surgery, Clinical Center "Mother Teresa" Skopje, Macedonia \\ ${ }^{3}$ Special Hospital for Orthopedic Surgery and Traumatology "St. Erazmo" - Ohrid, Macedonia \\ ${ }^{4}$ Clinic for Anesthesiology, Reanimation and Intensive Care, Clinical Center "Mother Teresa" Skopje, Macedonia \\ ${ }^{5}$ Medical faculty, University of "Ss. Cyril and Methodius" Skopje, Macedonia
}

Corresponding Author: Vladimir Mirchevski, University Clinic for Neurosurgery, Clinical Center "Mother Teresa" Skopje, Macedonia

\section{ABSTRACT}

Introduction: Prematurely fused metopic suture results in developmental anomaly named trigonocephaly. The treatment of trigonocephaly is a surgical reconstruction, starting from the simple suturectomy toward the complicated cranial vault reconstructions with aim to obtain enough endocranial space for normal development of the brain and aesthetic correction as well.

The aim: The aim of our paper is to present our experience on this pathology in the Republic of Macedonia, stressing the trigonocephaly as one of the rare forms of craniosynostosis.

Our material: During a period of 20 years (from 1996 to 2015) at the Pediatric department of the Clinic for Neurosurgery in Skopje, we observed 18 babies with trigonocephaly, including one with Carpenter syndrome and trigonocephaly, 14 males and 4 females. All children had simple trigonocephaly, one had syndromic trigonocephaly (Carpenter's syndrome). According to Oi and Matsumoto classification done in $1986^{5}$ severe trigonocephaly is observed in 11 cases and, moderate trigonocephaly in 7 cases.

Our method: Our treatment consisted of slightly modified Di Rocco's ${ }^{3}$ surgical procedure named "shell" operation, adding transposition of the "bone flap".

Results: The postoperative period was uneventful except for the expected forehead swelling. The babies were discharged from the hospital on average at the $8^{\text {th }}$ postoperative day. At the three months control after the surgery, the head had excellent aesthetic appearance, with regular psychomotor development according to the age of the patient (Fig 3a and 3b). We had no serious complications except the expected postoperative swelling of the forehead. All operated children had excellent "long term" aesthetic effect and normal psychomotor development. Conclusion: The early recognition of these anomalies including all craniosynostoses, the deformities of the newborn and infant's head and the preventive operative reconstruction would prevent abnormal disturbance of the psychomotor development during the child's growth. The multidisciplinary approach can prevent new disabled individuals in the society. Our technique allows shortening the entire surgical procedure, especially in the departments where blood saving devices are not available.

Key words: Craniosinostoses, trigonocephaly, our experience, operative reconstruction.

\section{INTRODUCTION}

Craniosynostoses represent developmental anomalies of the craniofacial growth in humans that is a premature adhesion of the sutures of the calvaria, which leads to craniostenosis, obstructing the normal psychomotor development of the infants. The consequences of the untreated craniosynostosis can be simple aesthetic disfigurations of the normal shape of the head, but also can lead to mental disruptions, 
difficulties in gaining new skills, disturbed behavior, epilepsy, hydrocephalus, headaches, damaging of the cranial nerves (I, II, V, VI, VII), endocrinopathies. ${ }^{6}$ The causes for the craniosynostoses are generally unknown, there are a lot of theories and possibilities: the teratogenic effect of the valproic acid, aminopterin, hydantoin, retinoic acid, oxymetazoline, diseases such as hyperthyroidism, rickettsiosis, thalassemia, sickle cell anemia, thyroid diseases in pregnant woman, shunt-induced after treatment of hydrocephalus, amniotic bands, mucopolysaccharidoses, genetic damages, especially of the genes FGFR1-3, NELL1, MSX2, TWIST and GLI3, 1,3,6

The principle of formation of the craniosynostoses has been modified in dependence of the thoughts and observations of the authorities. Virchow (1851) suspected that the craniosynostosis was a primary malformation while the deformity of the cranial base is secondary; Moss (1959) concluded that the malformation of the cranial base is the essence for appearance of premature fusion of the cranial sutures on the calvaria; and Park \& Powers (1920), suggested much more acceptable theory that the primary defect was located in the mesenchymal blast tissue that leaded to anomalies in the cranial vault and the cranial base. ${ }^{6}$

The incidence of craniosynostoses estimates approximately $0.1-1$ (0.6) from 1,000 live babies. ${ }^{4,6}$ The classification of craniosynostoses distinguishes two groups: nonsyndromic (primary, simple) craniosynostoses and syndromic craniosynostoses (conjoined with other developmental anomalies, usually on the extremities). ${ }^{3,4,6}$ The nonsyndromic craniosynostoses are divided depending on the suture that prematurely is closed, respectively, premature of the sagittal suture creates the dolichocephaly (scaphocephaly head with shape of a boat, the most common 56\%), prematurely fused coronal suture - brachycephaly (anterior unilateral - anterior plagiocephaly, 24\%, bilateral - acrocephaly, turricephaly, head in a shape of tower), prematurely fused metopic suture - trigonocephaly (wedge-shaped head, 4\%), prematurely closed lambdoid suture - posterior plagiocephaly, and premature closure of all sutures gives the form of oxycephaly. ${ }^{4,6}$ The syndromic craniosynostoses include the following syndromes: Crouzon, Apert, Pfeiffer, Saethre-Chotzen and Carpenter syndroms. ${ }^{1,2,4,6}$

Diagnosis of the craniosynostoses is made with physical examination of the child (inspection - characteristic shape of the cranial vault, palpation - a prominent thicken prematurely fused suture, volumetric measurements, cranial index, cranial perimeter), $\mathrm{x}$-ray of the skull, EEG, computed tomography with $3 \mathrm{D}$ reconstructions, magnetic resonance of the brain (for possible associated anomalies of the brain). ${ }^{1,2,4}$

The treatment of the craniosynostoses is surgical reconstruction, starting with the simple suturectomies going further to the complex cranial vault reconstructions with aim to create enough space for normal development of the brain and the aesthetic correction of the shape of the head as well.

The timing of the surgical procedure for the best result would be the age of 3 to 7 months of the infant. If the intervention is done before the 3 months of age, there is a high rate of recurrence of the craniosynostosis with a need for additional intervention. ${ }^{7}$

\section{THE AIM}

The aim of this paper is presenting our experience about this pathology stressing over the trigonocephaly as one of the rare forms of craniosynostosis.

\section{CLINICAL MATERIAL}

During the period of 20 years (from 1996 to 2015) in the Pediatric department of the Clinic for Neurosurgery in Skopje, Republic of Macedonia, we observed and treated 18 infant patients with trigonocephaly, including one with Carpenter syndrome and trigonocephaly, 14 males and 4 females. All children have simple trigonocephaly, one has syndromic trigonocephaly (Carpenter's syndrome with resistant lower respiratory infection, hypertonia and polydactyly with two thumbs on the right hand). The age of our patients ranged from 7 up to 14 month, an average of 9.5 months with median of 9 months. All children had pronounced trigonocephaly with cranial perimeter lower than 2 standard deviations, hypertonia has been observed in 8 cases and epileptic seizures have been observed in 3 cases. Psychomotor retardation has not been observed. The diagnosis has been confirmed with computed tomography with bone window and in some cases (mostly the latest) with computed tomography with $3 \mathrm{D}$ reconstructions of the skull. The measurements of the frontal angle, or of the angle between the two lines drawn through Pterion (bilaterally) and $\mathrm{Na}-$ sion, described by Oi and Matsumoto in $1986^{5}$, done on the axial CT slices showed a severe trigonocephaly in 11 cases and, moderate trigonocephaly in 7 cases.

\section{SURGICAL TREATMENT}

The procedure was done under general endotracheal anesthesia with the infant placed in supine position. The procedure began with bifrontal skin incision and creating of the frontal scalp flap. After 


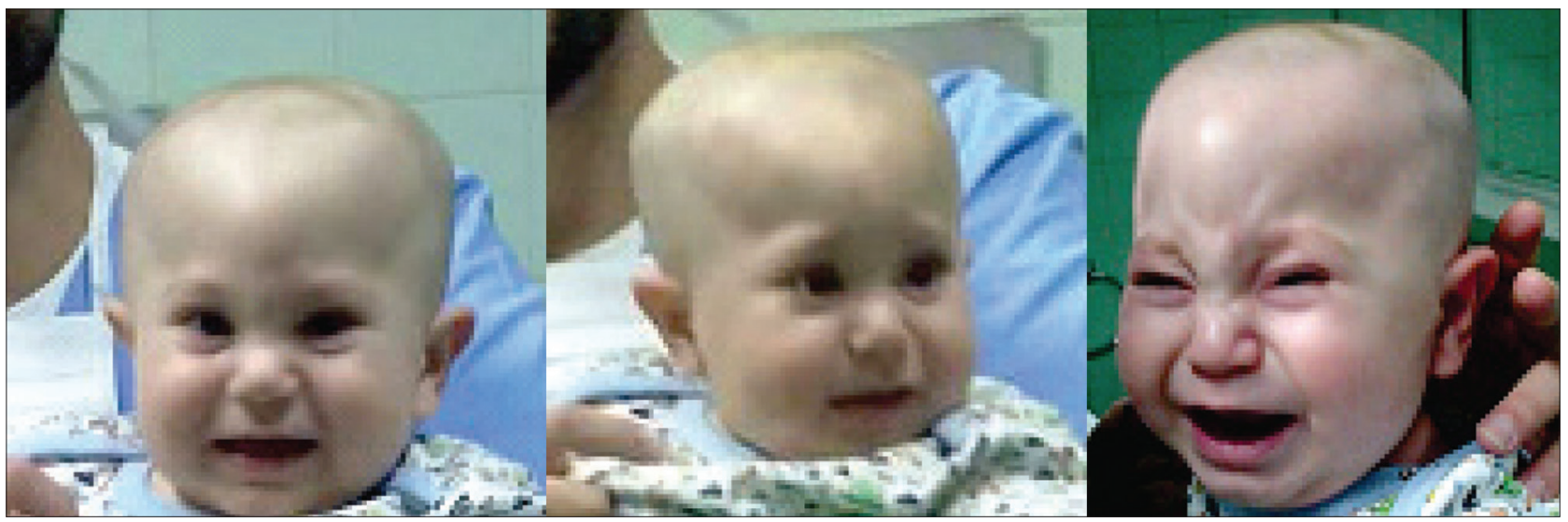

Figure 1. Preoperative trigonocephaly

the elevation of the periosteum, epidural dissection of the free edge of the frontal bone at the great

fontanel is performed, followed by the bifrontal craniotomy with one-piece free bony flap. The upper edge of the bony flap contained the coronal suture, spreading laterally downwards to the both temporal fossas. The lower edge of the bony flap has been made just over the supraorbital rims, after creating a "burr-hole" using diamond drill over the frontonasal suture where the biggest thickening of the metopic suture is observed. The bony flap has been diminished for $1 \mathrm{~cm}$ and rotated for 180 degrees.

The most prominent and thick part of the bone was excised, the midline of the bony flap was fractured in fashion of "green-stick" fracture and radial osteotomies were done for complete remodeling of the forehead. The bony flap was fixed forward and distal to the most front part of the cranial base through small bone holes on the free edge of the base with interrupted 2-0 silk sutures. Scalp flap closure has been done with interrupted Blair-Donatti 4-0 polypropylene sutures, without using epicranial drainage.

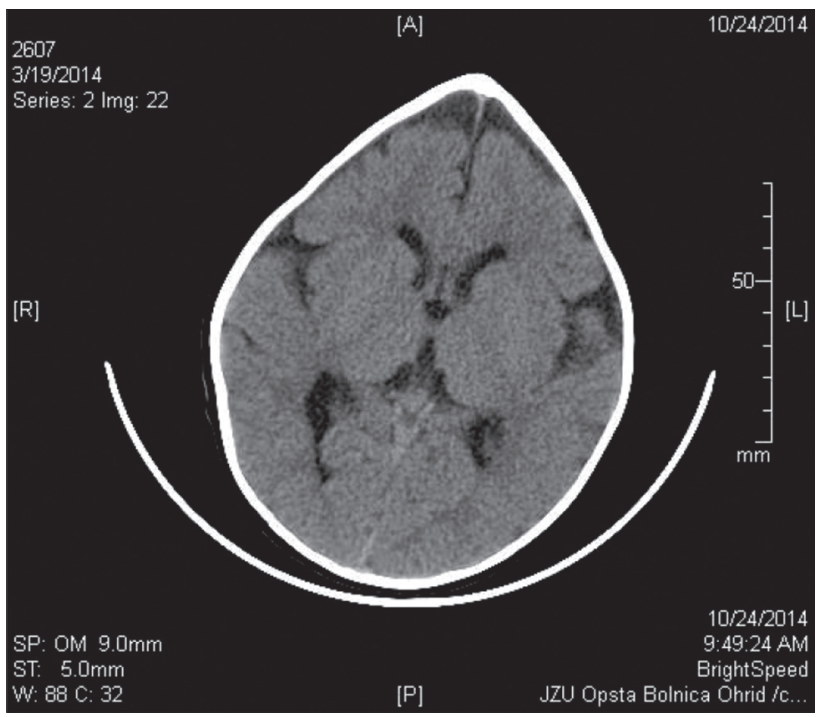

Figure 2. CT scan of the head in case with trigonocephaly

\section{RESULTS}

The postoperative period was uneventful except for the expected forehead swelling. The babies were discharged from the hospital in average on the $8^{\text {th }}$ postoperative day. At the three months control after the surgery, the head had excellent aesthetic appearance, with regular psychomotor development according the age of the patient. (Fig. $4 \mathrm{a}$ and $4 \mathrm{~b}$ ). The muscular tonus was better after the reconstruction and correction of the craniostenosis; no further resistant respiratory infections and opisthotonus have been observed. We did not have serious complications except the expected postoperative swelling of the forehead. All operated children had excellent "long term" aesthetic effect and normal psychomotor development. The patient with trigonocephaly and polydactyly in the case of the Carpenter syndrome underwent a second plastic and reconstructive surgery six months after the first surgery in order to reduce the number of fingers on his right hand.

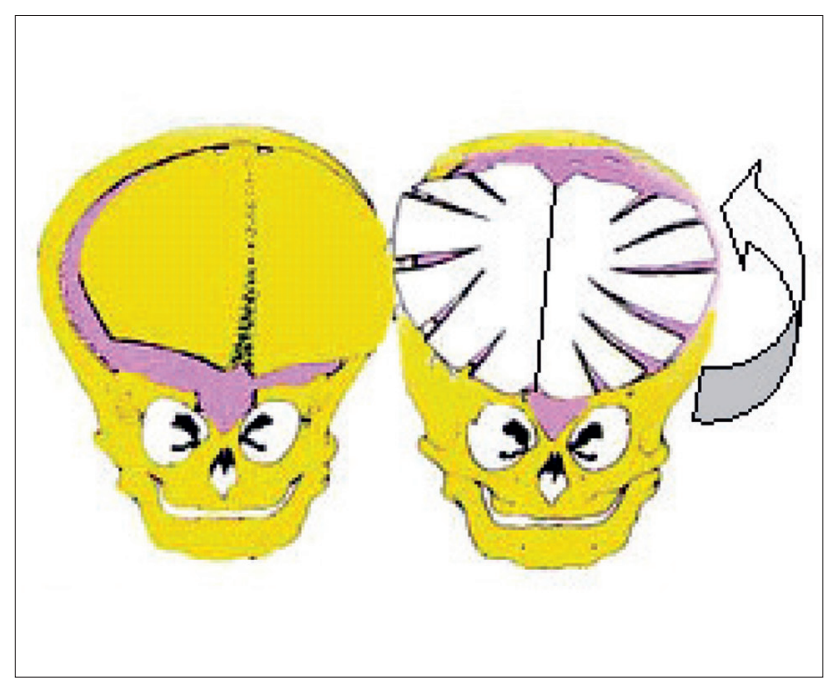

Figure 3. Reconstructed scheme of our treatment, modified Di Rocco "shell" procedure 3 


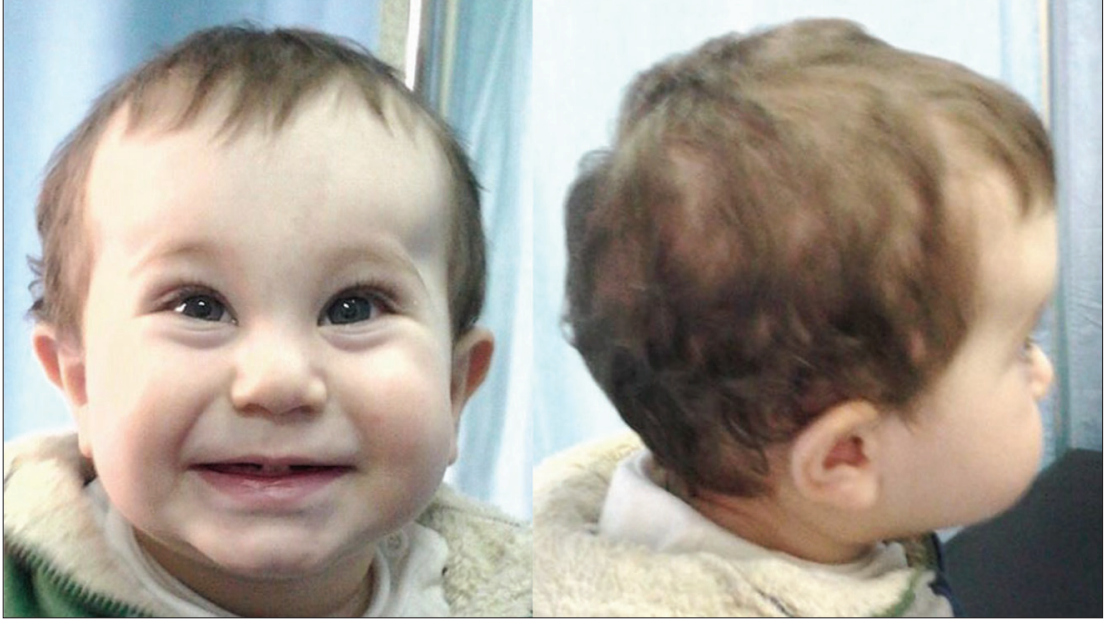

Figure 4a. The patient on Figure 1, two months after surgery

We have not observed other complications. The seizures were well controlled in 3 babies with preoperative phenobarbital treatment. The muscular tonus was better after the reconstruction and the correction of the craniostenosis, no further resistant respiratory infections and opisthotonus have been observed. We did not have serious complications except the expected postoperative swelling of the forehead. All operated children had excellent "long term" aesthetic effect and normal psychomotor development.

\section{DISCUSSION}

The treatment of the craniosynostoses is surgical reconstruction, starting with the simple suturectomies going further to the complex cranial vault reconstructions including the endoscopic minimal-invasive procedures. The alternative methods like the "conservative remodeling" with helmets are not complete reliable method for correction of these developmental diseases ${ }^{1}$. The eventual postoperative usage of the helmets can increase the effectiveness of the remodeling of the skull. There are a lot of surgical techniques of reconstructions or suturectomies, depending on the type and the severity of the craniosynostosis, the child's age, the association with other anomalies of the cranial base (hypotelorism, hypertelorism, midface malformations...). ${ }^{1,3}$

The trigonocephaly (premature fusion of the metopic suture) takes $4 \%$ of all simple non-syndromic craniosynostoses. ${ }^{6}$ The clinical appearance is typical, with wedge-shape, triangular forehead, flattened supraorbital rims, thickened metopic suture and cranial index with normal value. The computed tomography of the brain is also typical, with flattened bilateral frontal lobes and small anterior cranial fossa. The only treatment for trigonocephaly is the surgical

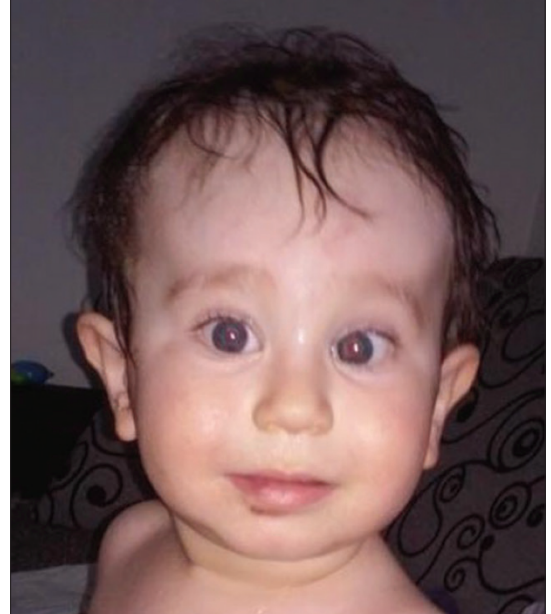

Figure 5b. The same patient five months after surgery

correction of the deformity. There are various numbers of operative interventions in which the common principle is reconstruction of the whole frontal bone, even including complex reconstructions with corrective osteotomies of the roof of the orbits and the lateral ends of the supraorbital rims for advancement and enlargement of the anterior cranial fossa.

Braid and Proctor ${ }^{1}$ suggest that the operative correction is done between the age of 6 and 12 months of the infant for open reconstruction of the anterior part of the vault because of the associated bigger blood lost, the durability of the intervention and the high rate of recurrence if the intervention is done before the age of 6 months of the infant.

Raimondi's ${ }^{7}$ opinion about the timing of 7 months of age with follow up do his 13 months of age, having excellent aesthetic effect and no signs of recurrence of the deformity, with normal psychomotor development. The age of our patients at the time of the intervention ranged from 7 to 14 months, an average of 13 months, with median of 9 months.

Apart from the endoscopic treatment, all open surgical procedures include bifrontal craniotomy, creation of free bony flap in one or two pieces, excision of the nasal extensions of the frontal bone and frontal extensions of the nasal bones, lateral advancement of the superior orbital ridges by pivoting on their sectioned or green-stick fractured medial edges, replacement of the frontal bony flaps after modifying their edges, curvature and orientation. The variations include the creation of a free orbital bar and its replacement after opportune remodeling, the insertion of a bone graft in the midline gap resulting from the removal of the upper part of the nasal bones to correct hypotelorism. ${ }^{3}$

Di Rocco's ${ }^{3}$ personal surgical technique reaches all the mentioned goals through a procedure named 
"shell" operation because of the characteristic form of the frontal bony flap. Essentially the procedure consists of a frontal craniotomy allowing to remove the deformed frontal bone and part of the parietal bones from a line $2 \mathrm{~cm}$ above the orbital ridges to the anterior fontanel. The flap is remodeled with the drilling of the thick ridge of the metopic suture and anterior displacement of its lateral aspects. Radial osteotomies converging downwards and towards the midline (so mimicking the lines of the shell) diminish the resistance of the bone and allow to modify its curvature. The nasal processes of the frontal bone and the upper part of the nasal bones are removed. The roof and the lateral walls of the orbits are sectioned and the lateral borders of the superior orbital ridges pushed forward in order to compensate for the hypoplastic orbital cavity. The pushing maneuver is made using the medial borders of the superior orbital ridges, cracked only partially, as pivots. The advancement is maintained by replacing the remodeled frontal bone between the advanced superior orbital rims and the anterior border of the parietal bones.

In our cases, there is a modification of the classic intervention with rotation of two free bony flaps without intervention over the superior orbital ridges. The created free frontal bone flap in one piece is osteotomized anteriorly and distally just above the superior orbital ridges with drilling of the most prominent part of the metopic suture and after that it's rotated for 180 degrees with excision of the most prominent wedge part of the bone flaps. The radial converging linear osteotomies are made on the bone flap with separate green-stick fractures for further enlargement of the intracranial space. The frontal bone flap is repositioned and fixed over the superior orbital ridges with one interrupted 2-0 silk suture on both sides of the forehead. The created reconstruction makes an excellent aesthetic and functional effect especially with the enlargement of the anterior and lateral aspects of the frontal lobes of the cerebrum.

The possible side effects of the intervention are bleeding, infection of the wound, with overall incidence under $1 \%$, possible recurrence with further need for additional surgical correction depending on the age of the patient and the type of the craniosynostosis. Our long term results show no complications, neither recurrences. Comparing our results with the results in the literature we observed no difference in the results with the classic surgical procedure for trigonocephaly. However our procedure is shorter and accompanied with less blood loss.

\section{CONCLUSION}

The early recognition of these anomalies including all craniosynostoses, the deformities of the newborn and infant's head and the preventive operative reconstruction would prevent abnormal disturbance of the psychomotor development during the child's growth. The multidisciplinary approach can prevent new disabled individuals in the society. Our technique allows shortening of the entire surgical procedure, especially in departments where blood saving devices are not available.

\section{BIBLIOGRAPHY:}

1. Baird L.C., Proctor M.R.: Craniosynostosis, Albright A.L., Pollack I.F., Adelson P.D. Principles and Practice of Pediatric Neurosurgery, 3th edition, Thieme : 237-248, 2014

2. David D.J., Poswillo D., Simpson D.: The Craniosynostoses: causes, natural history and management, Springer-Verlag, Trigonocephaly : 133-140, 1982

3. Di Rocco C.: Nonsyndromic craniosynostosis, Sandou M., Practical Handbook of Neurosurgery, SpringerWienNeyYork, Volume 2: 561582, 2009

4. Greenberg M.S.: Handbook of neurosurgery, $7^{\text {th }}$ edition, Thieme, Craniosynostosys : 228-232, 2010

5. Oi S, Matsumoto S. Trigonocephaly (metopic synostosis). Clinical, surgical and anatomical concepts. Childs Nerv Syst. 1987;3:259-265. doi: 10.1007/BF00271819

6. May D.: Craniosynostosis", "Neurosurgery 93 - A Manual for European Trainees in Neurosurgery", Newman Thomson Ltd, L.8, 1993

7. Raimondi A.J.: Pediatric Neurosurgery Theoretical Principles Art of Surgical Techniques, Springer Science+Business Media, LLC, Congenital anomalies : 379-398, 1998 


\title{
Резиме
}

\section{ТРИГОНОЦЕФАЛИЈА - НАШИ ИСКУСТВА И ТРЕТМАН ВО РЕПУБЛИКА МАКЕДОНИЈА}

\section{Владимир Мирчевски ${ }^{1}$ Елизабета Жоговска ${ }^{2}$, Александар Чапароски ${ }^{1}$ Миле Миќуновиќ ${ }^{3}$, Венко Филипче ${ }^{1}$, Мирко Мишел Мирчевски ${ }^{5}$, Миленко Костов ${ }^{1}$, Љубица Миќуновиќ ${ }^{4}$}

\author{
${ }^{1}$ Универзитетската клиника за неврохирургија, Клинички центар „Мајка Тереза“, Скопје, Македонија \\ 2 Универзитетска клиника за пластична, естетска и реконструктивна хирургија, \\ Клинички центар „Мајка Тереза“, Скопје, Македонија \\ ${ }^{3}$ Специјална болница за ортопедска хирургија и трауматологија „Св Еразмо“, Охрид, Македонија \\ ${ }^{4}$ Клиниката за анестезија, реанимација и интензивно лекување, Клинички центар „Мајка Тереза“, \\ Скопје, Македонија \\ ${ }^{5}$ Медицински факултет, Универзитет „Св. Кирил и Методиј“, Скопје, Македонија
}

\section{Апстракт}

Вовед: Прерано сраснатата метопична сутура резултира со развојна аномалија наречена тригоноцефалија. Третманот на тригоноцефалијата е хируршка реконструкција, почнувајќи од едноставни сутуректомии кон комплицирани реконструкции на кранијалниот свод, со цел да се добие доволно ендокранијален простор за нормален развој на мозокот и естетска корекција.

Цел: Целта на трудот е презентирање на нашите искуства во врска со оваа патологија во Република Македонија, нагласувајќи ја тригоноцефалијата како една од ретките форми на краниосиностоза.

Нашиот материјал: Во текот на 20 години (од 1996 до 2015 година) во Детскиот оддел на Клиниката за неврохирургија во Скопје опсервиравме 18 бебиња со тригоноцефалија, вклучувајќи и едно со синдром Карпентер и тригоноцефалија, 14 машки и 4 женски. Сите деца имаа едноставна тригоноцефалија, едно имаше синдромна краниосиностоза (синдром Карпентер). Според Класификацијата на Ои и Мацумото, направена во 1986 година ${ }^{5}$, тешка trigonocephaly е забележана во 11 случаи, а умерена тригоноцефалија во 7 случаи.

Нашиот метод: Нашиот третман се состои од малку изменета Дирокова ${ }^{3}$ хируршка процедура, наречена операција „школка“, додавајќи транспонирање на коскен резен.

Резултати: Постоперативниот период беше мирен, освен очекуваниот оток на челото. Бебињата се отпуштени од болница во просек на осмиот постоперативен ден. Три месеци по операцијата за контрола, главата имаше одличен естетски изглед, психомоторниот развој беше според возраста на пациентите(слика 3а и 3б). Немавме сериозни компликации, освен очекуваниот постоперативна оток на челото. Сите оперирани деца имаа одличен „долгорочен“ естетски ефект и нормален психомоторен развој. Оваа постапка овозможува скратување на оперативното време, посебно во институции каде што нема апарати за рециклажа на крв.

Заклучок: Со раното препознавање на овие аномалии, деформитетите на новороденчето и главата на бебето и превентивните оперативни реконструкции, ќе се спречи абнормално нарушување на психомоторниот развој за време на растот на детето. Мултидисциплинарниот приод може да ја спречи појава на нови лица со посебни потреби во општеството. Нашата техника овозможи скратување на целата хируршка процедура, особено во одделенијата каде што нема уреди за рециклажа на крв.

Клучни зборови: краниосиностоза, тригоноцефалија, наше искуство, оперативна реконструкција 